\title{
Krumi (Microorganisms) in Ayurveda- A critical review
}

\section{Review Article}

\section{Meena Shamrao Deogade ${ }^{1^{*}}$, Shiva Rama Prasad Kethamakka ${ }^{2}$}

\author{
1. Professor, Department of Dravyaguna, \\ Mahatma Gandhi Ayurved College Hospital and Research centre, Wardha, MS 442001 \\ 2. Professor and Head, Department of Panchakarma, \\ Lakshmi Narayan Ayurved College and Hospital, Bhopal-462042
}

\begin{abstract}
The microorganism or bacteria and their role in the cause of several infectious diseases have been recognized and elaborated in Ayurveda since Vedic period. There are many references relating to bacteria in ancient literature such as Rigveda, Atharveda, Shatapatha Bramhana etc. Krimi, Rakshas, Pishacha, Apsara, etc. terms are used for microorganisms and several types of microorganism have been recognized and described in Vedic literature. Some organisms are visible and macroscopic (Drishya) and some are of microscopic (adrishya). They may originate either inside or outside of the body. They have identified for the primary seat of infection (vesa) and the secondary seat of infection (parivesa) in the body. Ayurveda recommended four methods to destroy microorganisms; viz. refraining, disentangling, removing and fumigating. This paper attempts to review the Vedic and Ayurveda understanding of the microbes is essential here to follow the contemporary knowledge for recognition and development of microbiological science in Ayurveda.
\end{abstract}

Keywords: Krumi, Microorganism, Bacteria, Jeevanuvada, Ayurveda, Bhuta, Vaikarika, Avaikarika

\section{Introduction}

The Krumi (microorganism or bacteria) and their role in the cause of several infectious diseases have been recognized since Vedic period and elaborated in Ayurveda. There are many references pertaining to bacteria in ancient literature such as Rigveda, Atherveda, Satapadha - Brahmana, Taittireeya Upanidshad, Aranyaka, Chandyogyopanishad, Vishnupurana, Vayupurana, Bhagwatpurana, Raghuvansha, Kamasutra, Mahabharata (minute water borne microbes), etc. Ancient Indians were aware of the existence of microorganism or bacteria as well as causation of disease by them since Vedic period. The references in Vedas for microbes and infectious diseases are in the name of Krumi and Krumi Rogas. Krumi are thought to be the causative factors of many number of diseases by entering into the body to produces various diseases.

The knowledge of microorganism, both pathogenic and non-pathogenic could be traced to the well codified descriptions in various texts of Ayurveda. Many terms are used for microorganisms and approximately hundreds of microorganism have been recognized and described in Vedic literature. Krumi, Rakshas, Pishacha, Bhuta, Apsara and other terminologies are used for Krumi. The Visible or invisible minute organisms that affect on living and non living things of biosphere are described very efficiently in Ayurvedic science (1). Ayurveda recommended four

\section{*Corresponding Author:}

Meena Shamrao Deogade,

Professor, Department of Dravyaguna,

Mahatma Gandhi Ayurved College Hospital and

Research centre, Wardha, MS 442001

Email: drmmeena@rediffmail.com methods to destroy microorganisms; viz. refraining, disentangling, removing and fumigating (2) .

Pertinently it may be pointed out here that the modern pathologists might have even got some clue to the germ theory of diseases from Ayurveda. It is well known that with the beginning of the European contact with India many valuable manuscripts on science and culture were passed on to the West to interpret the knowledge treasured in them (3).

The harsh conditions in the urban industrialization leads to disease (4) and during the industrial revolution led to efforts in social reform preceding and contributing to sanitary reform even before the germ theory of disease causation was proven and the science of microbiology established. Pioneering breakthroughs, based on trial and error, challenged the established dogmas of the time, and produced the sanitary revolution, one of the important foundations of public health to control the microbes. Therefore modern pathologists should know the Vedic and Ayurveda understanding of the microbes are essential here.

\section{Materials and methods}

The literature on Krumi collected from all available classical as well as modern texts. Data studied, reviewed and the appropriate conclusions have been withdrawn from reviewed literature. Tried to identify and understand the terms used and types mentioned for microorganisms in ancient literature. This article will be helpful to know about microorganisms from ancient science.

\section{Observations and Discussion}

Krumi in vedic literature: Approximately hundred types of organisms have been identified to flourish in mountains, forests, plants, animals, water, 
etc. They flee through atmosphere and reach into food, water, milk etc., and invade the body through the food, sucks the blood, ruin the flesh, restrict the growth and cause diseases. Some organisms are visible and macroscopic (Drishya) and some are of microscopic (adrishya). They may originate either inside or outside of body. They have identified for their primary (vesa) and secondary (parivesha) seat of infection in the body (5) .

The worlds "Krumi" (which nourished by raw flesh), Rakshasa (which drinks blood), Yatudhana (which causes pain), Pisacha (Eats raw flesh), Apsara (Swims in water), Gandharva (Makes noise) etc. have been used to denote micro-organisms in Atharvaveda (6). Ayurveda used Krumi, jantu, jeevanu, etc to denote the same.

The organisms should be destroyed to mitigate the ill effect caused by them. Mantra, Bali, Homa, Manidharana (7) and Jambhavi were used to destroy these microorganisms. Either natural remedies like Sunrays, Fire, etc. $(8,9)$ or Guggulu, Aguru, Sarjarasa, Vacha, Sarshapa, Jatamasi, Nimba patra etc., dhopana along with sacred recitations (10) also destroy them. Sages like Atri, Agasthya, Kanva, Jamadagni, have recommended four methods to destroy them are refraining, disentangling, removing and fumigating. There are also some organisms which are useful to human beings such as 'Pinga' and 'Paidava.' Pinga preserves the baby at the birth and chases the amorous Gahandarvas away (11).

\section{Post Vedic Literature (Epics, Puranasa and Classics)}

Bhutas, Grahas, Rakshasas, Gandharvas and Pishachas were described in Kadambari (328-492), Harsha charitra (75), Abhijanshakuntala (3.24), Brihatsamhita (53-33), Mahaveera charitra(228), and Shankarbhasya and Brihadaranyakaopanished (3.31), Udara Krumis were narrated in Arthasashtra of Kautilya (4,78.3.17). Vedavyasa in his Mahabharata told that Krumis are everywhere and nobody can avoid them. Communicability of mahamari (Plague) from one person to another through rats has been indicated in Kalika purana in which people have been advised to quit their houses where rats dying or fall dead (12).

Bala grahas like Putana and Revati were mentioned in Brihatsamhita (3.3), Shremadbhagwata (6.6.14), Vishnupurana (5.5.723), Markandeyapurana (43-9), and Vayupurana (9.89). These diseases were thought to be very difficult to be cure at that time. The symptoms of Balgrahas and their treatment have been maintioned in vishnupurana $(1-231,32)$. Kalidasa has observed that the grahas enter the body as the image enters the mirror in his Raghuvamsa (16.6), Shri Shankaracharaya has observed that they destroy the smriti in his commentary on Chandogyopanishat. Vatsayana has observed that persons suffering from Rajayakshama were used to be isolated from the society. The method of vaccination for prevention of masurika (small pox) was also described in Sakteya grandha of Dhanvantri which was revoked by the present day scientists.

\section{Ayurveda literature}

Ayurveda, the science of life, based on principles routed from Vedas was gradually evolved for centuries. It had developed to its hugeness, that it had been divided into 8 branches by Sushruta in $5^{\text {th }}$ cent B.C. Bhuta (microbes) Vaidyam (Vidya) (13) is one among them that mimics present day bacteriology. There are a vast number of citations available in Ayurvedic literature pertaining to Jeevanuvada or bacteriology.

Vishamajwara (malaria and typhoid) is associated with blood and Bhuta (Microbes) termed as Satata (fever always) and Santata (fever alternative). The treatment for this fever is practiced as wearing precious stones and herbs, chanting sacred verses, Antitoxic (microbial toxins) medicines, etc. (14). Vagbhata has observed that all the diseases are communicable (sancharanseela). Sushruta and vagbhata have recognized innumerable diseases that are contagious (shankramaka) or infectious (15). They have also indicated the association of microorganism with some diseases. The diseases which are considered as communicable by Ayurveda are kushta (leprosy and other skin diseases), Jwara (fever), sosha (tuberculosis), netrabhishyanda (opthalmias and some eye diseases), upadamsa (syphilis), bhutonamada (neurological upsets). Romantika, Masurika, (small pox), Granthi (tumours), Visarpa (Erysipelas), Apasmara and Seetalika. Gayadasa the commentator on Sushruta Samhita has illustrated the communicability of diseases with example of spared of Masurika.

In connection with the prognosis of seven kinds of leprosy (Kustha) Charaka has mentioned the presence of bacteria or microbes under the term of "Krumi" and "Jantumanti". Charaka affirms that the "Krumi is found in the blood vessels (16) in microscopic size $(A n u)$, circular or disc like (Vritta) etc. He further corroborates the microbial aetiology of Kushta and says that these microbes or krumis, at certain advanced stages, start invading the skin (twak), flesh (mamsa), blood (rudhira), blood vessels (sira dhamani), tendons (snayu) and cartilages (tarunasthi). Similarly Susruta also advocated the microbial aetiology of kushta and states "Sarvani kusthani savatani sapittani saslemani sakrminica" which means Krumis or bacteria along with Tridosa (Vata, Pitta and Kapha) are involved in the causation of all kinds of Kushta (17).

In dealing with other diseases Charaka classifies five kinds of brain diseases as Siroroga. He states that "Panca siroroga" as "Vata, Pitta, Kapha, sannipata, Krumijah" (18). With all probability, this Krumija variety of brain disease may/can be equated with the diseases of the meningo coccal infection or precisely Meningitis. Likewise in the aetiology of chest diseases (Hrudroga) Charaka confirms bacterial origin as one out of five causes. Thus Charaka says "Pancahrid roga iti Sirorogairvyakhyatah" (19). In Charaka Sutra $19^{\text {th }}$ chapter, it has a generalization of the pathogenic organisms that are classified in to twenty varieties $(20,21)$. The classification in total is as follows in the Figure 1. 
Figure 1: Classification of Ayurvedic Microbial theory Krumi

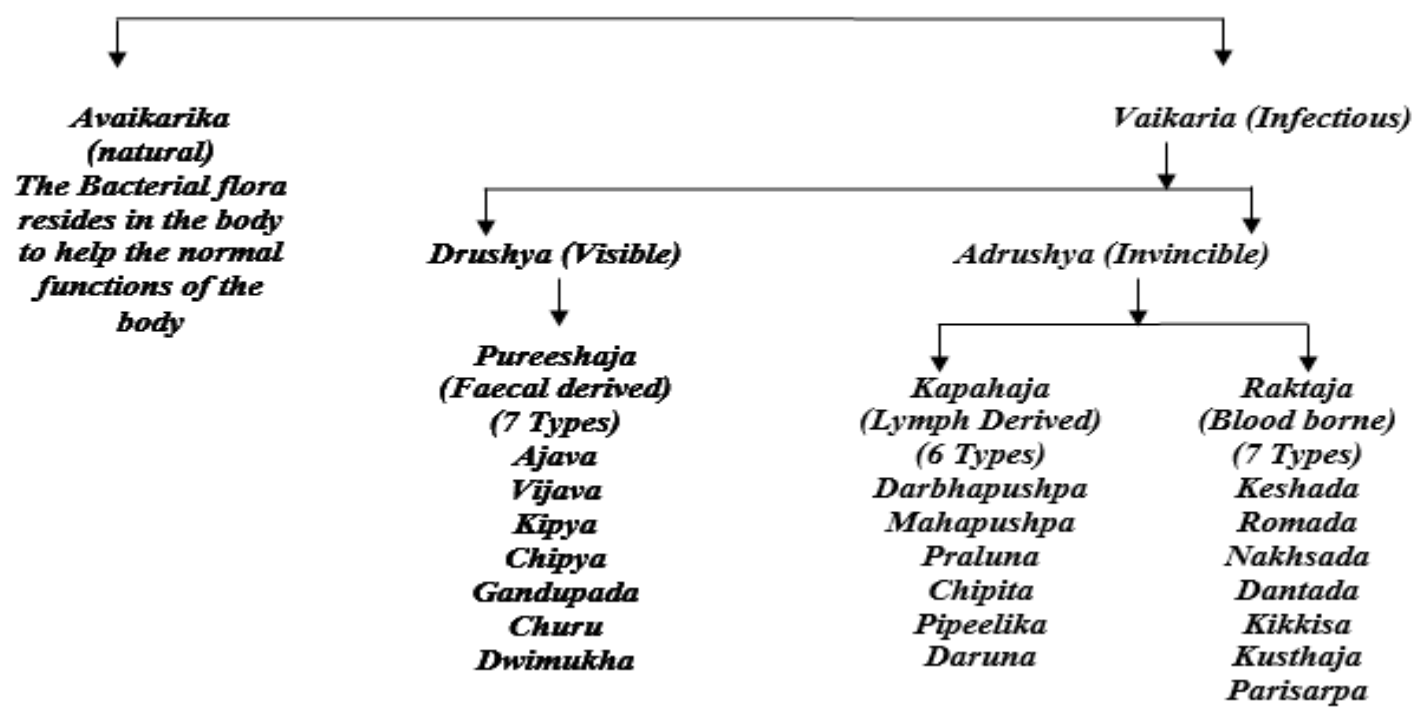

Ayurveda classics classified organisms into Avaikarika/ Sahaja (natural) and Vaikarika/ agantu (pathogenic or invaders). Out of twenty varieties two are originated from external origin for which he termed as 'Bahirmalaja' (external biowaste derivateves). The six varieties are in situ with blood. The blood born are named as 'Kesadah' Lomadah', Lomadwipah', Saurasah' 'Audumbarah' and 'Jantumatarah'. Charaka stated seven varieties of Krumis of lymphatic origin viz, 'Antradah', 'Udaradah', 'Hridayacarah', 'Cyuravah', 'Darbhapuspah', 'Saugandhikah', 'Mahagudah'. The Last group of krumi are five varieties of faecal origin. They are termed 'Kakerukah', 'Makerukah', 'Sasulakah', 'Lelihah' and 'Sausuradah'(22). It is quite pertinent to note here that according to Charaka there are in all, 13 varieties/groups of pathogenic micro-organisms of blood and lymphatic origin. Curiously enough, according to the modern bacteriology there are mainly about 14 groups of pathogenic microbes, viz. Coccus, Neisseria, Cornebacterium, Fungi, Endamoeba, Haemophylus, Clostridia, Mycobacterium, Brucella, Pasteurella, Salmonella, Shigella, Coliform and Vibrios (23).

Ayurvedic diagnostics has codified this knowledge of bacterial aetiology of diseases in a very precise manner in his treatise - Madhava Nidana (24) with a dedicated chapter on 'Krumi nidana' (bacterial pathology). Madhava Nidana primarily makes two broad divisions of Krumis according their availability in human body viz. internally and external. Then he makes further typology according to origin viz. External excretes like sweat (Bahirmalajah), lymphatic tissues (Kapha), blood (Asruk) and faeces (pureesha). This main grouping of Madhava covers all the twenty varieties of Krumis, as defined by Charaka earlier. However, Vijayaraksita, the commentator of Madhava Nidana, throws further light on the state of microorganisms as there are some non-pathogenic organisms existence by the name 'Sahaja

Krumis' (natural or healthy microbes) as opposed to the former groups 'Sanjata Krumis' (infective microbes) which are infectious in origin (25).

Further, Madhava Kara has described various pathological manifestations, which take place with bacterial infection in general, and says that there may be fever (Jwara), paleness (Vivarnata), various kinds of pain (sulam), chest affection (Hridroga), loss of physical coordination (Sadanam), coma (Bhrama), apathy for food (Bhaktadwesha) and diarrhoea (Atisara). Next, it is quite striking to note there about the knowledge of communicable diseases held by the ancient Ayurvedic authorities. Naturally communicability of diseases definitely presupposes the existence of pathogenic microorganisms - through the agency of which only infection can run from one person to another under various kinds of personal contacts. Shri Kantha datta in his Madhukosa commentary has observed that the Aupasargika rogas are caused due to papa and Bhutapasarga. The term Bhutapasarga indicate invasion of bacteria. The different mode of infection spread described by Ayurveda is depicted in table- 1 .

It is mesmerizing to find that the Sushruta Samhita mentions about communicable diseases and the way of it spreads from one person to the other by contact. He has mentioned the modes of transmission of disease as- sexual contact by touching someone who is infected, frequent interaction with the diseased person, physical contact of the body, through breath, by eating together, by sitting together, by sleeping together and by wearing the same garlands and ornaments (26). There is reference of epidemic diseases found in Charaka samhita. It is clearly mentioned that such diseases spread and kill large number of people at the same time (27). There are also interesting observations on communicable diseases, epidemics and infection. This indicates that ancient Ayurvedic physicians were aware of microscopic life i.e. Krumi or microorganisms. 
Table 1: According to Ayurveda different mode of infection

\begin{tabular}{|l|l|}
\hline Prasanga & $\begin{array}{l}\text { Contagious (Sexual or intimate } \\
\text { contact) infection }\end{array}$ \\
\hline Gatrasamsparsa & Bodily contact infection \\
\hline Nishwasa & Air borne infection \\
\hline Sahabhojana & $\begin{array}{l}\text { Food borne infection (Bacterial } \\
\text { contamination /Food Poison) }\end{array}$ \\
\hline Sahasayya & $\begin{array}{l}\text { Contact (Sexual or intimate contact } \\
\text { through sharing bed) infection }\end{array}$ \\
\hline Sahaasana & $\begin{array}{l}\text { Contact (intimate contact / sitting } \\
\text { together) infection }\end{array}$ \\
\hline $\begin{array}{l}\text { Vastramalya } \\
\text { anulepana }\end{array}$ & $\begin{array}{l}\text { Contact (common wearing of cloths } \\
\text { and cosmetics) infection }\end{array}$ \\
\hline
\end{tabular}

\section{Conclusion}

To summarize the Vedic and Ayurvedaic understanding of the microbes is essential here to follow the contemporary knowledge. The Vedic literature is well known with infection and its invasion over blood, flesh, and other organs through air, water, food borne contamination and spread. Ancient physicians were aware of not only pathogenic organisms but also non-pathogenic organisms that naturally inhabited the human body. A reference found in Aștānga Hṛdaya, illuminates that the pathogens of the blood are indeed totally invisible to the human eye and are therefore microscopic. Therefore the term krumi comprise worms, bugs, parasites, and probably microorganisms also.

\section{References}

1. Raghuveer, Rao V N, Ayurvedic concept of Krumi, Journal of Biotechnology and Biosafety Volume 2 ( 5); 2014. 150-155p

2. Ganjam Purushottamacharyulu, Basic principles of Ayurveda, Bacteriology in Ancient indian Literature, Sharma DP (editor), 14th chapter of Basic Principles of Ayurved, 1st ed, Patna; Shree Baidyanath Ayurved Bhavan, 1978,104-6p

3. Sircar NN, Ancient Indian Bacteriology, Ancient Science of Life, Vol 10(3); 1991.180 - 184p

4. Acharya Agnivesha, Charaka Samhita. Kashinath Pande (editor), Vol 1. Chikista stana 1/4/4, Varanasi; Chaukhamba bharati Academy; 2001. $51 \mathrm{p}$

5. Jayadev Sharma, Atharvaveda Samhita, 1st ed, Volume-1, 2/32/5, Ajmer; Arya sahitya Mandal, 1985. $194 \mathrm{p}$

6. Ganjam Purushottamacharyulu, Basic principles of Ayurveda, Bacteriology in Ancient indian Literature, Sharma DP (editor), 14th chapter of Basic Principles of Ayurved, 1st ed, Patna; Shree Baidyanath Ayurved Bhavan, 1978,104-6p

7. Acharya Agnivesha, Charaka Samhita. Kashinath Pande (editor), Volume-1, sutra 11/54, Varanasi; Chaukhambha bharati Academy; 2001.238p

8. Acharya Susruta. Susruta Samhita. Shastri A (editor). Reprint Vol I. Utta. Varanasi;Chaukhamba Sanskrit Sansthan; 2005. 398p
9. Jayadev Sharma, Atharvaveda Samhita, Volume-1, 2/32/3, 1st ed, 1985, Ajmer, Arya sahitya Mandal; 1985. $192 \mathrm{p}$

10. Acharya Susruta. Susruta Samhita. Shastri A (editor). Reprint Vol I. Sutra 5/18. Varanasi;Chaukhamba Sanskrit Sansthan; 2005. 25p

11. Saligrama K, Rao R, Encyclopaedia of Indian Medicine: Historical perspective Vol-1, 2nd ed, Bangalore; Dr Parameshvara Charitable trust, 2005.p27

12. George J, Roche F. Encyclopaedia of religions, Vol3, New Delhi; Cosmo publications, 2005. 236p

13. Acharya Susruta. Susruta Samhita. Shastri A (editor). Reprint Vol I. Sutra 1/7. Varanasi;Chaukhamba Sanskrit Sansthan; 2005. 3p

14. Acharya Agnivesha, Charaka Samhita. Kashinath Pande (editor), Volume-1, chi 3/309, Varanasi; Chaukhambha bharati Academy; 2001.170p

15. Acharya Susruta. Susruta Samhita. Shastri A (editor). Reprint Vol II. Nid. 5/32-33. Varanasi;Chaukhamba Sanskrit Sansthan; 2005. $251 \mathrm{p}$

16. Acharya Agnivesha, Charaka Samhita. Kashinath Pande (editor), Volume-1, Vim. 7/11, Varanasi; Chaukhambha bharati Academy; 2001.726p

17. Acharya Susruta. Susruta Samhita. Shastri A (editor). Reprint Vol II. Nid. 5/19-20. Varanasi;Chaukhamba Sanskrit Sansthan; 2005. $250 \mathrm{p}$

18. Acharya Agnivesha, Charaka Samhita. Kashinath Pande (editor), Volume-1, Su. . 17/27-28, Varanasi; Chaukhambha bharati Academy; 2001.335p

19. Acharya Agnivesha, Charaka Samhita. Kashinath Pande (editor), Volume-1, Su. 17/37, Varanasi; Chaukhambha bharati Academy; 2001.337p

20. Acharya Agnivesha, Charaka Samhita. Kashinath Pande (editor), Vol 1. sutra 3/6, Varanasi; Chaukhamba bharati Academy; 2001.391p

21. Acharya Vagbhata. Vagbhata Samhita, Gade G K (editor). Ed 8, Nidana 14/42-43. Pune; Raghuvanshi Prakashana; 1996.208p

22. Acharya Susruta. Susruta Samhita. Shastri A (editor). Reprint Vol II. Uttara. 54/8/ 12. Varanasi;Chaukhamba Sanskrit Sansthan; 2005. $400 \mathrm{p}$

23. WHO, Microbial fact sheets, http://www.who.int/ water_sanitation_health/ dwq/GDW11rev1and2.pdf, handled on $25.6 . \overline{2} 016,11 \mathrm{pm}$

24. Madhavakar, Madhava Nidana. Bramhanand tripath (editor) Vol-1, 7/1- Varanasi; Vijayarakshita, Surabharati Prakashan,;7 chapter 300-308p

25. Madhavakar, Madhava Nidana. Bramhanand tripath (editor) Vol-1, 7/1- Varanasi; Vijayarakshita, Surabharati Prakashan,;7 chapter 301p

26. Acharya Susruta. Susruta Samhita. Shastri A (editor). Reprint Vol 1. Varanasi; Nidana 5/32-33. Chaukhamba Sanskrit Sansthan; 2005. 325p

27. Acharya Agnivesha, Charaka Samhita. Kashinath Pande (editor), Vol 1. vimana 3/6, Varanasi; Chaukhamba bharati Academy; 2008. 693p 